\title{
THE ACTING PERSON ON THE U.S.-MEXICO BORDER
}

Revisiting Karol Wojtyla’s Idea of Being a Neighbor

\author{
Irene Ludji \\ Claremont Graduate University \\ irene.ludji@crgu.edu
}

\begin{abstract}
This article discusses the importance of being a neighbor, as understood through Karol Wojtyla's idea of "the acting person," in the context and experience of the migrants and humanitarian volunteers on the U.S.-Mexico border. There are three parts to this article. In the first part, I discuss the reality that migrants and humanitarian volunteers face at the U.S.-Mexico border. Migrants live in a liminal and violent space at the border, and the volunteers choose to enter this space to meet the vulnerable others. In the second part, I examine an idea presented by then-Cardinal Karol Wojtyla in his book The Acting Person. In the book-published in 1969 before he became Pope John Paul II in 1978-Wojtyla addresses the importance of being a neighbor through conscious participation in actions "together with others" for the achievement of the common good. In the third part, I present a critical reflection on the connection between migrants' context and humanitarian work experience at the U.S.-Mexico border and Wojtyla's idea of the acting person as a neighbor. By putting the idea of a neighbor in dialogue with the context of the U.S.-Mexico border, I intend to broaden Wojtyla's thought to address the contemporary circumstances at the border.
\end{abstract}

Keywords: humanitarian, Karol Wojtyla, migrants, neighbor, the acting person, U.S.-Mexico border

Abstrak
Artikel ini membahas gagasan Karol Wojtyla tentang the acting person
yang diletakan dalam konteks migran dan sukarelawan
kemanusiaan di perbatasan Amerika Serikat dan Meksiko. Artikel
ini terbagi atas tiga bagian. Pada bagian pertama, dibahas konteks
yang dihadapi oleh migran dan sukarelawan kemanusiaan di
perbatasan Amerika Serikat dan Meksiko. Para migran harus


menghadapi berbagai bentuk kekerasan di perbatasan, dan para sukarelawan kemanusiaan memilih untuk bersama-sama berjuang dengan mereka untuk keluar dari situasi ini. Pada bagian kedua, dijelaskan ide-ide utama yang dipresentasikan oleh Karol Wojtyla dalam buku "The Acting Person" yang diterbitkan pada tahun 1969 sebelum ia ditabiskan menjadi Paus Yohanes Paulus II pada tahun 1978. Di dalam buku tersebut, Karol Wojtyla membahas pentingnya konsep the acting person lewat partisipasi secara sadar dalam tindakan solidaritas dengan orang lain untuk mencapai kebaikan bersama (common good). Pada bagian ketiga, disajikan refleksi kritis tentang hubungan antara konteks migran dan pengalaman kerja kemanusiaan di perbatasan Amerika Serikat dan Meksiko dengan gagasan Wojtyla tentang the acting person sebagai sesama manusia (neighbor). Dengan menempatkan ide Karol Wojtyla dalam dialog dengan konteks di perbatasan Amerika Serikat dan Meksiko, saya berharap dapat memperluas aplikasi pemikiran Wojtyla dalam diskusi kontemporer.

Kata-kata Kunci: kemanusiaan, Karol Wojtyla, migran, sesama manusia, perbatasan Amerika Serikat-Meksiko, the acting person.

In her book Borderlands: La Frontera, Gloria Anzaldúa defined the border as "una herida abierta (an open wound) where the Third World grates against the First and bleeds." A border is a vulnerable place. At the border, migrants are perceived as unworthy "illegal transitory intruders" with almost no rights and deserving of no support. ${ }^{2}$ Further, since the early 1990s, an estimated five thousand individuals have died while attempting to cross the U.S.-Mexico border. ${ }^{3}$ The high number of deaths on the U.S.-Mexico border raises this question: "Why would migrants risk crossing the border knowing that they will be putting their lives in danger?" The obvious answer is that they are seeking a better life, or escape from an intolerable one. Still, Miguel A. De La Torre

1 "The U.S-Mexican border es una herida abierta where the Third World grates against the First and bleeds. And before a scab forms it hemorrhages again, the lifeblood of two worlds merging to form a third country - a border culture. Borders are set up to define the places that are safe and unsafe, to distinguish us from them. A border is a dividing line, a narrow strip along a steep edge. A borderland is a vague and undetermined place created by the emotional residue of an unnatural boundary. It is in a constant state of transition. The prohibited and forbidden are its inhabitants." Gloria Anzaldúa, Borderlands = La Frontera: The New Mestiza (San Francisco, CA: Aunt Lute Books, 1999), 25.

2 Wendy A. Vogt, "Crossing Mexico: Structural Violence and the Commodification of Undocumented Central American Migrants," American Ethnologist, Vol. 40, No. 4 (2013): 776, https://doi.org/10.1111/amet.12053.

${ }^{3}$ Kristin E. Heyer, Kinship across Borders : A Christian Ethic of Immigration (Washington, DC: Georgetown University Press, 2012), 4. 
notes an important underlying reality: most of the migrants on the border "would rather remain in their homeland, but instead are forced to leave for the insecurity of border crossing because [of] the US created political and economic uncertainty in their country due to a foreign policy designed to secure the avarice of multinational corporations.",

The border is a liminal ${ }^{5}$ space where migrants must survive if they want to make it to the other side of the border. The humanitarian volunteers who work there have chosen to enter this liminal space of migrants on the U.S.-Mexico border to meet the needs of those vulnerable others. In this article, I will argue that humanitarian work should be done with the acknowledgment of one's duty to be a neighbor. This relationship lies at the core of a person's conscious action "together with others." "This conscious action-as detailed in the work of Karol Wojtyla-is performed as a practice of solidarity, a particular type of participation that focuses on working with others to achieve the common good. In addition, solidarity, in Wojtyla's understanding, goes beyond mere feeling and affection; it is an act that enables persons to be a neighbor with others.

This article is divided into three parts. In the first part, I discuss the reality that migrants and volunteers face at the U.S.Mexico border. In the second part, I examine Karol Wojtyla's idea of the acting person and address the importance of being a neighbor through conscious actions. The scholarly literature that examines the struggle on the U.S.-Mexico border from the perspective of theological ethics is already plentiful, including these pieces: Agnes M. Brazal and Maria Teresa Davila in Living With(out) Borders: Catholic Theological Ethics on the Migration of Peoples; Helen T. Boursier in The Ethics of Hospitality: An Interfaith Response to US Immigration Policies; Gemma Tulud Cruz in Toward a Theology of Migration: Social Justice and Religious Experience; Kristin E. Heyer in Kinship Across Borders: A Christian Ethic of Immigration; and Miguel A. De La Torre in The US Immigration Crisis: Toward an Ethics of Place. However, amid the abundance of this literature, sources that stress humanitarian work using the lens of The Acting Person-which is precisely what this article is aiming at-is still minimal. In the third part, I reflect on the connection between the context of migrants

\footnotetext{
${ }^{4}$ Miguel A. De La Torre, The U.S. Immigration Crisis: Toward an Ethics of Place (Eugene, OR: Cascade Books, 2016), 151-152.

${ }^{5}$ Liminal: Characterized by being on a boundary or threshold, esp. by being transitional or intermediate between two states, situations, etc. "Liminal," in Oxford English Dictionary Online, accessed July 28, 2020, https://www-oedcom.ccl.idm.oclc.org/view/Entry/108471? redirectedFrom=liminal.

${ }^{6}$ Karol Wojtyla, The Acting Person, Analecta Husserliana, Vol. 10, ed. Anna-Teresa Tymieniecka, trans., Andrzej Potocki (Dordrecht, Holland: D. Reidel Publishing Company, 1979), 276.
} 
and the experience of humanitarian work at the U.S.-Mexico border and Wojtyla's idea of the acting person as a neighbor.

\section{The Context of Migrants and the Experience of Humanitarian Work at the U.S.-Mexico Border}

Border-crossing deaths have occurred at a rate of at least one in every twenty-four hours since fortification intensified along the border between the US and Mexico in the mid-1990s ${ }^{7}$ Almost half of the unauthorized migrants are female, and they are three times more likely to die during the journey as the result of sexual assault. ${ }^{8}$ Migrants on the move have to deal with many kinds of life-threatening situations. ${ }^{9}$ This life-threatening situation includes "drowning, suffocation in overcrowded and perilous cargo transport, mutilations from accidental or coerced train injuries, fatal dehydration, high rates of physical violence, detention under inhuman conditions, and precious little recourse to protection or legal representation." ${ }^{\prime 10}$ Despite the rescue efforts from different institutions and humanitarian organizations, the number of deaths on the U.S.-Mexico border continues to climb. ${ }^{11}$

The rapidly increasing number of migrant deaths has led to the initiation of humanitarian work that focuses on supplying aid to help the migrants survive their journey along the US-Mexico border. ${ }^{12}$ On the US side of the border, one of those organizations, established in 2004, is No More Deaths (NMD). ${ }^{13}$ NMD is a part of movements that oppose the current systematic approach that diminishes migrants' human rights. For their work, NMD has received support as well as criticism and threats. For example, in July 2005, two NMD volunteers were arrested and charged for carrying three migrants to a nearby hospital to receive medical aid. ${ }^{14}$ As they face the challenges of carrying out their humanitarian efforts, humanitarian volunteers on the border remain firm in their commitment to and passion for bringing aid to the vulnerable migrants. ${ }^{15}$ On the Mexican side of the border, the situation looks even worse for migrants and humanitarian volunteers. Migrants are experiencing a range of types of assault, brutality, and

${ }^{7}$ Heyer, Kinship Across Borders, 4.

${ }^{8}$ Ibid., 8.

${ }^{9}$ Ibid., 62.

10 Ibid., 8-9.

${ }^{11}$ Ibid., 9.

${ }^{12}$ Leif Johnson, "Material Interventions on the US-Mexico Border: Investigating a Sited Politics of Migrant Solidarity," Antipode, Vol. 47, No. 5 (2015): 1243-1260, https://doi.org/10.1111/anti.12151.1

13 Ibid., 4-5.

${ }^{14}$ Jill M Williams, "From Humanitarian Exceptionalism to Contingent Care: Care and Enforcement at the Humanitarian Border," Political Geography, Vol. 47 (2015): 11, https://doi.org/10.1016/j.polgeo.2015.01.001.

${ }^{15}$ Johnson, "Material Interventions on the U.S.-Mexico Border," 1245. 
exploitation. ${ }^{16}$ The humanitarian volunteers have received threats from the government and organized criminals who believe that humanitarian work will jeopardize their political and business interests. ${ }^{17}$ Instead of stepping back, many humanitarian volunteers endure the threats while standing courageously with the migrants.

Kristin E. Heyer believes that migrants are put into a situation where risky and sometimes fatal migration is the only survival option. ${ }^{18}$ Heyer states that as the result of the North American Free Trade Agreement (NAFTA) in 1994, "millions of Mexicans lost their jobs in agriculture and many have been forced to abandon their land and join irregular migrant streams to the United States, most without legal protection." ${ }^{19}$ For Heyer, the struggle of the migrants on the border reveals the problem with these immigration and trade policies. ${ }^{20}$ When migrants are viewed as threats, the government initiates immigration policies and the protection of borders knowing that the price of these policies is the loss of migrant lives. The argument then protects violation of human rights on the border that these are necessary safety measures and legal issues.

As migrants move across the border from Mexico into the United States, they often plan their trip based on the known locations of the humanitarian organizations stationed near the border. On the U.S.-Mexico border, humanitarian organizations provide a variety of shelter types for migrants. There are temporary buildings that serve the purpose of shelter, and there are also permanent buildings complete with bedrooms, bathrooms, and kitchens. ${ }^{21}$ Wendy A. Vogt recalled from her research on the U.S.Mexico border that at one of the shelter offices, a map documenting migrant deaths along the US-Mexican border served as a dire warning about what will happen to the migrants after they leave the shelters. ${ }^{22}$ The border-because it is a space where the undocumented status of the migrants becomes apparent, while, at the same time, they are also becoming disconnected from their familiar social ties and communities-makes them most vulnerable to mistreatment. ${ }^{23}$ Subsequently, research has shown that the journey across the border for migrants has become a space known for extreme violence, discrimination, and exploitation. ${ }^{24}$

\footnotetext{
16 Vogt, "Crossing Mexico," 764.

${ }^{17}$ Ibid., 776.

${ }^{18}$ Heyer, Kinship Across Borders, 10.

${ }^{19}$ Ibid.

${ }^{20}$ Vogt, "Crossing Mexico," 62.

${ }^{21}$ Ibid., 766.

22 Ibid.

${ }^{23}$ Ibid., 765.

${ }^{24}$ Ibid., 764.
} 
From the humanitarian work side, the borders made it possible for volunteers to enter the migrants' vulnerable space. This space of "Los intersticios," 25 or the liminal space, also calls for care on the part of the humanitarian workers, because it is already space where migrants lack control and experience loss of dignity. Humanitarian organizations that commonly provide food and shelter on the border are morally responsible not only to fill the migrants' basic needs but also to protect their rights as human beings. ${ }^{26}$ The aid that is provided through humanitarian work "should be more than an impersonal delivery of goods but rather should be given in a way that recognizes the dignity of the recipient in various ways, including providing them a space to have some control over the circumstances of their fate." ${ }^{27}$ The violence perpetrated towards migrants along the border further impersonalizes their existence; such harm puts extra stress on the relationship between the humanitarian organizations and the migrants, as the migrants are experiencing an extreme loss of control. That being stated, I would not want to imply that only violence calls for solidarity. The main goal is to exhibit equality and promote agency in the relationship between migrants and humanitarian volunteers. Thus, humanitarian volunteers who typically think of themselves as giving something to the migrants must look for ways to correct and rebalance their relationship with migrants to emphasize the protection of their sacred human rights. $^{28}$

Based on this brief presentation of the context and experience of migrants and humanitarian workers, it is clear that there is an urgent need to address the lack of justice for migrants on the U.S.-Mexico border. An approach that focuses on the person and the value of her agency is needed in analyzing our ethical responsibility to the migrants on the border, because that approach enacts human rights for all human beings, including the migrants.

\footnotetext{
25 Anzaldúa, Borderlands, 54.

${ }^{26}$ Vogt, "Crossing Mexico," 766.

27 Michael Barnett, "The Humanitarian Act: How Humanitarian?," International Social Science Journal, Vol. 65, No. 215-216 (2014): 13, https://doi.org/10.1111/issj.12072.

${ }^{28}$ John Doering-White, "The Shifting Boundaries of 'Best Interest': Sheltering Unaccompanied Central American Minors in Transit through Mexico," Children and Youth Services Review, Vol. 92 (2018): 41, https://doi.org/10.1016/j.childyouth.2018.01.009.
} 


\section{The Acting Person: Interweaving Personalism and Communalism}

An analysis that is based on the acknowledgment of a person's conscious act with others in solidarity for the achievement of the common good can provide a valuable contribution to the discussion of dehumanizing practices towards migrants on the border. Accordingly, Karol Wojtyla's work in The Acting Person ${ }^{29}$ is used in this analysis. His synthesis of the concepts of personalism and communalism within the acting person is beneficial to understanding our ethical obligation towards each other, especially with the migrants on the border. Wojtyla preferred the term "person" instead of "individual" because, for him, it captures an essential element that guarantees the practice of conscious action concerning an existing human being. Wojtyla affirms that "the human being as the person-seen in its basic ontological structure-is the subject of both existence and acting." ${ }^{30}$ Comprehending the concept of personhood in Wojtyla's account is critical. Still, his recommendation does not stop there: his goal is not only to establish the ethics of personhood. I believe that understanding the concept of personhood in Wojtyla's work is a compelling starting point, leading us to go further and appreciate his idea of human interdependency, or a person's being and acting together with others. Through this relation of a person "together with others," solidarity will appear most significantly as an ethical duty.

In his discussion, Wojtyla describes three characteristics necessary to the acting person. In Kevin P. Doran's words, these are self-knowledge, self-possession, and self-fulfillment. ${ }^{31}$ The first characteristic of the acting person is self-knowledge or consciousness. ${ }^{32}$ Doran explains, "The knowledge of oneself precisely as person is the basis on which it is possible to understand and accept the personal reality of others." ${ }^{33}$ Only a self-aware person can perceive her actions as deliberate extensions of her thinking and intentions. "In the Western philosophical tradition a deliberate action has been seen as the actus bumanus, the human act,

${ }^{29}$ The Acting Person (Osoba I C\&yn/ Person and Act) is considered Karol Wojtyla's masterpiece. “The book was the product of Wojtyla's attempt to marry the Aristotelian-Thomistic notion of person to Schelerian theory of consciousness." Jovito Cariño, "Review of Person, Action and Love: The Philosophical Thoughts of Karol Wojtyla (John Paul II) by Jove Jim S. Aguas," Kritike, Vol. 11, No. 1 (2017): 235, https://doi.org/10.25138/11.1.b1.

${ }^{30}$ Wojtyla, The Acting Person, 74.

31 Kevin Doran, Solidarity: A Synthesis of Personalism and Communalism in the Thought of Karol Wojtyla/John Paul II (New York: P. Lang, 1996), 125.

32 Ibid.

${ }^{33}$ Ibid., 126. 
with the stress laid on the aspect of purpose and deliberateness," he continues. ${ }^{34}$ Actus bumanus is understood as the act of the human person that involves knowledge and will, and hence must be recognized as a moral act. This is different from actus hominis, which is the act of a human being that lacks knowledge and will, and therefore is not a moral act. ${ }^{35}$ Adding to the understanding of actus bumanus, Wojtyla claims that "consciousness constitutes a specific and unique aspect in human action." 36 Consequently, one has the self-understanding as a product of consciousness that is revealed through conscious acting. ${ }^{37}$

In Solidarity: A Synthesis of Personalism and Communalism in the Thought of Karol Wojtyla/Pope John Paul II, Doran states that Wojtyla differentiates between two forms of consciousness: first is "a conscious acting" and second is "a consciousness in which the person experiences himself as a subject of action." 38 In the first form, "consciousness accompanies and reflects or mirrors the action when it is born and while it is being performed; once the action is accomplished consciousness still continues to reflect it, though of course it no longer accompanies it." ${ }^{39}$ In other words, conscious acting is the consciousness that exists when a person acts.

The second form of consciousness is a person's awareness of her conscious action, both with respect to her essence and with respect to her behavior. According to Doran, Wojtyla calls this the "reflective" function "because it recalls consciousness, as it were, from its intentional object, and gives the human subject to it, as its object instead." consciousness, however, the acting person becomes aware of himself not only as subject (i.e., the one in whom the experience is happening), but also as actor (i.e., the one who is the cause of what is happening)." ${ }^{41}$ In this form of consciousness, a person becomes aware of her action and the responsibility that comes with those actions. To repeat, according to Wojtyla, an act can only be 1, co.

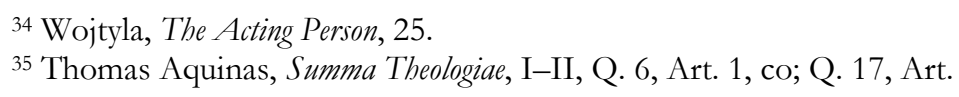

36 Wojtyla, The Acting Person, 30-31.

${ }^{37}$ Gerard Beigel, Faith and Social Justice in the Teaching of Pope John Paul II (New York: Peter Lang, 1997), 11.

${ }^{38}$ Doran, Solidarity, 127.

${ }^{39}$ Wojtyla, The Acting Person, 31.

${ }^{40}$ Doran, Solidarity, 127.

${ }^{41}$ Ibid. Doran uses both the term reflective and reflexive in his analysis. According to the Oxford English Dictionary, reflective means thinking deeply about things while reflexive (of an action) is refers to an act performed as a reflex or without conscious thought. Wojtyla in The Acting Person uses the term reflexive but added to the term the need for consciousness to exist in a reflexive act. For Wojtyla, it is a conscious reflexive act that counts as a characteristic of the acting person. 
acknowledged as an action based on the consciousness of the action and consciousness that it is the person who acts.

The second characteristic of the acting person in Wojtyla's work is self-possession. Because the consciousness of oneself will lead to actions that engage one's will and potency, a person through her conscious action determines who she becomes. ${ }^{42}$ Doran states that "the first act of every person is the act of being itself, but this act is in turn a potency to further or conjugate act by means of which the person determines himself accidentally, through the exercise of his own freedom." 43 Transcendence here means "that the person, as it were, steps beyond the boundaries of his fixed nature." ${ }^{44}$ In experiencing her consciousness, through which one exercises her potency and will, a person transcends herself in action.

The third characteristic of the acting person is selffulfillment. Consciousness, as discussed by Wojtyla, is not merely a cognitive work. It is true that "the self-fulfillment of the person in action depends on the recognition of the truth, which is a cognitive act, but it depends equally on the surrender of the will to the truth." ${ }^{45}$ Therefore, acting in unity with the truth fulfills the self. Further, self-fulfillment achieved through the combination of will and cognitive work forms a sense of duty and obligation. ${ }^{46}$ Doran states, "It is only because of the structures of self-determination and self-fulfillment that man's willing of objects external to himself has any lasting personal significance." ${ }^{47}$ One's actions shape one's being, and so when one does good, she becomes good, and vice versa, when one does bad, she becomes bad. ${ }^{48}$ On the whole, in Wojtyla's analysis, the ethical duty of a person towards others is founded on acknowledging one's consciousness, leading to the commitment towards the other person.

According to Doran, Wojtyla notes that a person's duty toward others relates to living in the community together, which implies adaptation in a person's relations with others. ${ }^{49}$ This adaptation arises from the fact that a person is a part of a community and must participate in it. ${ }^{50}$ Wojtyla describes participation as acting "together with others." According to Gerard Beigel in Faith and Social Justice in the Teaching of Pope John Paul II,

42 Ibid., 130.

${ }^{43}$ Ibid., 131.

${ }^{44}$ This is what Wojtyla called a vertical transcendence. Woityla also talks about horizontal transcendence, in which a person transcends herself "by possessing objects which are outside himself." Doran, Solidarity, 131.

${ }_{45}$ Doran, Solidarity, 135.

46 Wojtyla, The Acting Person, 156.

${ }^{47}$ Doran, Solidarity, 135.

${ }^{48}$ Ibid.

${ }^{49}$ Ibid., 142.

${ }^{50}$ Wojtyla, The Acting Person, 279. 
Wojtyla envisions participation as occurring in two steps: "First, the capacity of participation means that when the person acts together with others, he 'retains in this acting the personalistic value of his own action." 51 Participation brings personal fulfillment. In addition to this self-fulfillment, a person consciously acts together with others in communal acting. ${ }^{52}$ To repeat, in participation, a person deliberately acts as herself with others and comprehends that act as a shared or collective effort.

For Wojtyla, participation includes two kinds of interpersonal relations, i.e., $I$-You relations and $W e$ relations. ${ }^{53}$ The first type of participation is the $I-Y o u$ relation. In this kind of relation, a person realizes that the other is not only you in her consciousness but also an $I$, a subject like herself. ${ }^{54}$ In this experience of the other, one sees the other as a person who is not identical to herself without entering into the experience of the other's subjectivity. ${ }^{55}$ The second type of participation is the we relation. This relationship "involves a plurality of persons experiencing themselves as a definite we." ${ }^{56}$ In the we type of participation, "the human $I$ finds itself more fully and fundamentally precisely in the human we. ${ }^{, 57}$ As a result, a person, as a member of the community, acknowledges the good of the community as the good for all.

However, Doran reminds the reader that "in so far as a community is not a subject, but only a quasi-subject, it only makes sense to speak of the 'attitude of a community' if it is understood as the holding in common, or together, of personal attitudes by a plurality of persons, in respect of one or more other persons." ${ }^{, 58}$ Wojtyla stresses that when a person acts "together with others" as part of the community, the community does not become the subject of the act. Wojtyla considers that the consciousness of a person in the dynamic interrelation with others is a part of a person's consciousness. Hence, there is no such thing as the consciousness of the community; there is only consciousness of persons in the community. A person who acts together with others "only introduces new relations among the persons who are the real and actual subjects of acting." 59 This relationship is a foundational aspect of the community that acts together.

In The Acting Person, Wojtyla moves within the dynamic of participation to the idea of solidarity. Wojtyla defines solidarity as

${ }^{51}$ Beigel, Faith and Social Justice, 22-23.

52 Ibid.

${ }^{53}$ Doran, Solidarity, 142. In The Acting Person, Wojtyla discusses the topic of intersubjectivity by participation in Chapter 7 .

${ }^{54}$ Ibid., 143.

55 Ibid.

56 Ibid., 144.

${ }^{57}$ Ibid., 145.

58 Ibid., 151.

${ }^{59}$ Wojtyla, The Acting Person, 277. 
"a constant readiness to accept and to realize one's share in the community because of one's membership within that particular community." ${ }^{60}$ Wojtyla confirms that solidarity is the authentic attitude of the acting person in the community. "Just as action presupposes the experience of oneself as subject, co-action necessarily involves some sense of the other as subject, without any loss of the experience of one's own subjectivity." ${ }^{\prime 1}$ When a person pays consistent attention to others' subjectivity, a pattern of goodwill emerges. The constant goodwill to grasp one's responsibility within the community exists "not only because of his membership in the group but because he has the "benefit of the whole' in view -he does it for the 'common good." 62 Solidarity focuses on the significance of consciousness in the act of a person; this focused solidarity creates and transforms the common good for the community. Solidarity makes it possible for persons to become neighbors and to see others as neighbors to themselves.

\section{On Being a Neighbor: The Acting Person and Solidarity on the Border}

As I approach the final part of this article, I would like to recapitulate the central point made thus far. In the first part of this article, I presented the context of migrants and humanitarian work experience on the U.S.-Mexico border. Admittedly, the struggle that migrants have to face on the border demonstrates a violation of human dignity. Hence, the support provided by humanitarian organizations for these migrants must not only focus on their physical needs for food and shelter but also, most importantly, must be grounded in respect towards their dignity and rights as human beings. The foundation of humanitarian work essentially lies in work with others based on the acknowledgment of their rights.

The struggle of migrants inhabiting the liminal and vulnerable space on the border presses all of us as human beings to confront our world's highly problematic approach to the rights of other human beings. A thorough examination of the struggle of migrants and the problem of migrants' rights exceeds the scope of this article. However, I trust that this article will bring forward, in a small step, the discussion on the importance of solidarity as an ethical approach understood through the work of Wojtyła in The Acting Person. By applying his concept of solidarity, we can genuinely do good: because the solidarity approach is based on acknowledging every person's rights, it leads to the will to engage in promoting the good of the others. However, as indicated above,

\footnotetext{
${ }^{60}$ Ibid., 285.

${ }^{61}$ Doran, Solidarity, 142.

${ }^{62}$ Wojtyla, The Acting Person, 285.
} 
one might ask whether this humanitarian work is truly a work of solidarity, given the privilege that humanitarian volunteers have compared with the migrants. Volunteer humanitarians do their work because they see a troubling moral crisis involved in the situation on the border. This tremendous moral challenge confronts those involved. Thus, for those engaged at the core of humanitarian work, their action goes beyond doing something for others, and instead, must entail doing something with others: there lies the true meaning of moral responsibility, which is conscious participation together with others for the achievement of a common good.

The partnership toward a common moral goal unites humanitarian volunteers with the migrants as equals. Recognizing the actions in humanitarian work as an effort of solidarity means that we recognize the importance of respect for human rights. In turn, that respect is vital to transforming a discriminatory system that exists through the creation of borders. The acting person on the border connects all those who stand together in solidarity. These include the humanitarian volunteers who are consciously acting with others to transform the unjust system that leads to violation of migrants' human rights on the border. To repeat, humanitarian work "should be more than something done for or to others - it should be done with others." ${ }^{63}$

In the second part of this article, I have presented Wojtyla's idea of the acting person as a concept that synthesizes personalism and communalism. Wojtyla's analysis begins with the key elements of self-knowledge, self-possession, and self-fulfillment in a person; then it moves towards the duty of a person within the context of participation. That duty turns participation in solidarity. Thus, Wojtyla's discussion of participation understands that solidarity is related directly to a person's moral responsibility. Wojtyla focuses on "the growth, in wholeness, and in human dignity which happens in each individual when solidarity is practiced." ${ }^{64}$ Solidarity rests in the acknowledgment of human rights, and that acknowledgment leads a person to action that promotes moral justice. Solidarity leads us to see and treat the other as our neighbor ${ }^{65}$ - for the migrant, the worker is neighbor, and for the worker, the migrant is neighbor. When a person decides to act together with others, she participates with a consciousness that is aware of herself, her act of participation, and her participation with others.

\footnotetext{
${ }^{63}$ Barnett, The Humanitarian Act, 13.

${ }^{64}$ Marie Vianney Bilgrien, Solidarity: A Principle, an Attitude, a Duty? Or the Virtue for an Interdependent World? (New York: P. Lang, 1999), 19.

${ }_{65}$ Thomas D. Williams, Who Is My Neighbor?: Personalism and the Foundations of Human Rights (Washington, DC: Catholic University of America Press, 2005), 303.
} 
Hence, participation through solidarity is the crucial element for an acting person to be a neighbor to others.

\section{Conclusion}

Following Wojtyla's discussion in The Acting Person, it is clear that solidarity is founded on conscious action conducted by persons who stand together to fight against injustice, oppression, and those practices that dehumanize other human beings. Respect for human rights must lead to acting according to a person's moral duty towards others. Solidarity, as Wojtyla promotes it, goes beyond mere feeling and affection-solidarity is a "a firm and persevering determination to commit oneself to the common good; that is to say to the good of all and of each individual, because we are all really responsible for all." ${ }^{\prime 66}$ In solidarity, "no one is more a person than anyone else." ${ }^{97}$ As a person, it is one's responsibility to recognize the other as a subject with her unique ends and to act accordingly. ${ }^{68}$

The word "neighbor" is rooted in the word néahgebur (néah means near and gebur means dweller). ${ }^{69}$ This nearness not only stands for physical distance but also serves as a reminder of our nearness as human beings. Nearness means that beside each other, we are equal beings who deserve each other's respect and are all obligated to work together with each other to achieve the common good. Solidarity enables us to be "near" for others: to be a neighbor. Together, we are called to be the acting person and to stand close by one another and be a neighbor together for others. Neighbors stand together to achieve the common good, thereby protecting the vulnerable and engaging as partners in human dignity. A neighbor readily participates with others in situations that require action to achieve a common good. A neighbor does not build fences because fences separate by fostering barriers and separation. Instead, a neighbor stands close by in active engagement to protect those who are made vulnerable because of the building of fences. To be truly human, one must be with the other. This is the call for all communities everywhere: a call to be an acting neighbor..

\section{About the Author}

Irene Ludji, Ph.D. (cand.) is completing a doctoral program at Claremont Graduate University, California. She is a lecturer at the

\footnotetext{
${ }^{66}$ John Paul II, “Sollicitudo Rei Socialis," encyclical letter, December 30, 1987, sec. 38, http://www.vatican.va/content/john-paulii/en/encyclicals/documents/hf_jp-ii_enc_30121987_sollicitudo-reisocialis.html.

${ }^{67}$ Williams, Who is My Neighbor?, 164.

${ }^{68}$ Ibid., 163.

69 "Neighbor," in Merriam-Webster Dictionary, accessed July 28, 2020, https://www.merriam-webster.com/dictionary/neighbor.
} 
Faculty of Theology, Satya Wacana Christian University, Indonesia, and an ordained pastor from the Timor Reformed Church (Gereja Masebi Injili di Timor). Her research interests include Christian Ethics, Social Ethics, and Ecological/Animal Ethics.

\section{Bibliography}

Anzaldúa, Gloria. Borderlands $=$ La Frontera: The New Mestiza. San Francisco, CA: Aunt Lute Books, 1999.

Aquinas, Thomas. Summa Theologiae. I-II.

Barnett, Michael. "The Humanitarian Act: How Humanitarian?" International Social Science Journal, Vol. 65, No. 215-216 (2014): 13-24. https://doi.org/10.1111/issj.12072.

Beigel, Gerard. Faith and Social Justice in the Teaching of Pope John Paul II. New York: Peter Lang, 1997.

Bilgrien, Marie Vianney. Solidarity: A Principle, an Attitude, a Duty? Or the Virtue for an Interdependent World?. New York: P. Lang, 1999.

Cariño, Jovito. "Review of Person, Action and Love: The Philosophical Thoughts of Karol Wojtyla (John Paul II) by Jove Jim S. Aguas.” Kritike, Vol. 11, No. 1 (2017): 235-237. https://doi.org/10.25138/11.1.b1.

Doering-White, John. “The Shifting Boundaries of 'Best Interest': Sheltering Unaccompanied Central American Minors in Transit through Mexico." Children and Youth Services Review, Vol. $92 \quad$ (2018): 39-47. https://doi.org/10.1016/j.childyouth.2018.01.009.

Doran, Kevin. Solidarity: A Synthesis of Personalism and Communalism in the Thought of Karol Wojtyla/John Paul II. New York: P. Lang, 1996.

Heyer, Kristin E. Kinship across Borders: A Christian Ethic of Immigration. Washington, DC: Georgetown University Press, 2012.

John Paul II. "Sollicitudo Rei Socialis." Encyclical letter, December 30, 1987. http://www.vatican.va/content/john-paulii/en/encyclicals/documents/hf_jpii_enc_30121987_sollicitudo-rei-socialis.html.

Johnson, Leif. "Material Interventions on the US-Mexico Border: Investigating a Sited Politics of Migrant Solidarity." Antipode, Vol. 47, No. 5 (2015): 1243-1260. https://doi.org/10.1111/anti.12151.

La Torre, Miguel A. De. The U.S. Immigration Crisis: Toward an Ethics of Place. Eugene, OR: Cascade Books, 2016.

"Liminal." In Oxford English Dictionary Online. Accessed July 28, 2020. https://www-oedcom.ccl.idm.oclc.org/view/Entry/108471?redirectedFrom=1 iminal.

“Neighbor.” In Merriam-Webster Dictionary. Accessed July 28, 2020. 
https://www.merriam-webster.com/dictionary/neighbor.

Vogt, Wendy A. "Crossing Mexico: Structural Violence and the Commodification of Undocumented Central American Migrants." American Ethnologist, Vol. 40, No. 4 (2013): 764 780. https://doi.org/10.1111/amet.12053.

Williams, Jill M. "From Humanitarian Exceptionalism to Contingent Care: Care and Enforcement at the Humanitarian Border." Political Geography, Vol. 47 (2015): 11-20. https://doi.org/10.1016/j.polgeo.2015.01.001.

Williams, Thomas D. Who Is My Neighbor?: Personalism and the Foundations of Human Rights. Washington, DC: Catholic University of America Press, 2005.

Wojtyla, Karol. The Acting Person. Analecta Husserliana, Vol. 10. Ed., Anna-Teresa Tymieniecka, trans., Andrzej Potocki. Dordrecht, Holland: D. Reidel Publishing Company, 1979. 